\title{
Surface Areas of Cottons and Modified Cottons Before and After Swelling as Determined by Nitrogen Sorption ${ }^{1}$
}

\author{
Florence H. Forziati, Robert M. Brownell, and Charles M. Hunt
}

\begin{abstract}
Surface areas of cottons differing in variety and maturity, and cottons that had been subjected to various physical and chemical treatments were measured before and after swelling. Swollen cottons were prepared by immersing air-dried cottons in water at room temperature for 24 hours, displacing the water with methanol and the methanol with pentane, and finally drying the fibers. Surface areas were calculated from the quantity of nitrogen adsorbed at $-195.8^{\circ} \mathrm{C}$.

The specific surfaces of unswollen fibers were less than 1 square meter per gram; those of the swollen fibers ranged from 4 to 148 square meters per gram. Purification and mercerization produced increases in the surface available after swelling; methylenation produced a decrease; ethylamine treatment had no effect. In the early stages of methanolysis, a decrease in the surface available after swelling occurred; in the later stages, an increase.

Although surface area measurements were probably in no instance made on completely swollen fiber, the procedure employed is believed to be useful in evaluating the effects of various treatments on cottons and other cellulose fibers.
\end{abstract}

\section{Introduction}

The extent to which the surface area of the cotton fiber increases when the fiber is in contact with water is believed to have an important bearing on the performance of the fiber during processing and use. Hence, as a part of an investigation of the surface properties of cotton fibers, it was desired to obtain reliable surface-area measurements of the fibers both before and after swelling in water.

In earlier work at the National Bureau of Standards $[1]^{2}$, the surface area of purified cotton linters, as calculated by the equation of Brunauer, Emmett, and Teller [2] from data on the sorption of nitrogen was found to increase from 0.7 to $47 \mathrm{~m}^{2} / \mathrm{g}$ when the linters were swollen in water, subjected to a process of solvent exchange, and carefully dried. This suggested, as had the work of Assaf, Haas, and Purves $[3,4]$, that the solvent exchange and drying procedure might be used to stabilize cellulose in the expanded condition resulting from swelling, thus making it possible to apply the method of Brunauer, Emmett, and Teller to the measurement of the specific surface of swollen as well as unswollen fibers. The results of such measurements on a number of cottons differing in variety, maturity, and previous history are discussed in this paper.

\section{Materials and Methods}

The cottons used in this investigation were purified cotton linters; commercial absorbent cotton; 8 raw cottons representing 7 varieties and ranging in maturity from 38 to 96 percent; dewaxed cotton; cotton that had been dewaxed and then purified by open boiling in 1-percent sodium hydroxide solution; cotton that had been dewaxed and then purified by kierboiling in 1-percent sodium hydroxide solution;

1 A report of work done under cooperative agreement with the United States Department of Agriculture and authorized by the Research and Marketing Act. The work was supervised by the Southern Regional Research Laboratory of the Bureau of Agricultural and Industrial Chemistry.

2 Figures in brackets indicate the literature references at the end of this paper. cotton yarn purified by open boiling in alkali; cotton yarn purified by kierboiling in alkali; dye resistant and full-dyeing methylenated cottons; mature and immature cottons mercerized without tension; cotton yarn treated to reduce the crystallinity of the fiber; hydrocellulose; and 7 methanolyzed cottons. The linters were from the same lot as those used by Hunt, Blaine, and Rowen [1]. The raw cottons were supplied by E. L. Skau, R. A. Rusca, C. F. Goldthwait, and H. O. Smith; the open-boiled and kierboiled yarns by C. F. Goldthwait and H. O. Smith; the hydrocellulose and yarn of reduced crystallinity by C. M. Conrad; the methylenated cottons by C. F. Goldthwait; and the methanolyzed cottons by R. E. Reeves. ${ }^{3}$ These cottons are described further in the following section of this paper.

Nitrogen-adsorption measurements were made with an apparatus similar to that described by Emmett [5], using the procedures recommended by Barr and Anhorn [6]. Surface areas were calculated from the adsorption data by methods previously described $[2,5,7]$. In making the calculations, it was assumed that the nitrogen molecule covered an area of $16.2 \mathrm{~A}^{2}$.

For measurements on unswollen cottons, the airdried sample was tightly packed into a glass holder, and a sealed glass tube was inserted above the sample to reduce the "dead space." The holder was then sealed and attached to the adsorption apparatus. When the quantity of cotton permitted, 20- to $30 \mathrm{-g}$ samples were used for the nitrogen-sorption measurements; when it did not, 2- to 3 -g samples were used, with a consequent decrease in the precision of measurement.

For measurements on swollen cottons with their greatly increased surface areas, $1-\mathrm{g}$ samples were employed. The cotton was swollen by immersion in distilled water for approximately $24 \mathrm{hr}$ at room temperature, and then transferred to a sample holder, which was then attached to the apparatus used in the

${ }^{3}$ Members of the staff of the Southern Regional Research Laboratory of the U. S. Department of Agriculture. 


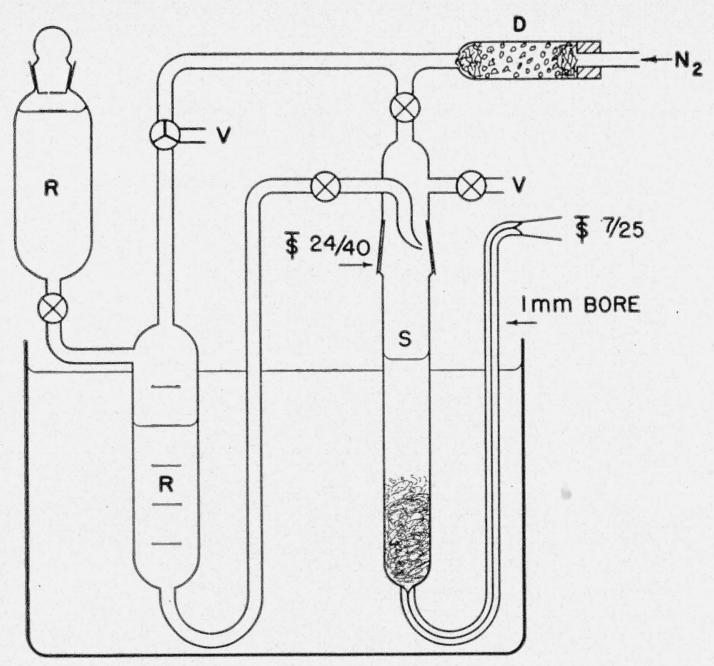

FIgURE 1. Solvent exchange apparatus.

$\mathrm{R}$, Solvent reservoirs; $\mathrm{V}$, vents; $\mathrm{S}$, sample holder; $\mathrm{D}$, drying tube.

solvent exchange process (fig. 1). This apparatus was so constructed that liquids were moved by an applied gas pressure on to the sample and subsequently forced through the sample, without the latter at any time being accessible to atmospheric moisture. The water was replaced by anhydrous methanol, which was added in five $10-\mathrm{ml}$ portions, each portion being allowed to remain in contact with the sample for 5 min before being replaced by the succeeding portion. The methanol was replaced by five 10-ml portions of anhydrous pentane in exactly the same way. The sample holder was removed to an ice bath, and the pentane was driven off by a stream of dry nitrogen, $50 \mathrm{ml} / \mathrm{min}$, passing through the sample for $24 \mathrm{hr}$. A sealed glass tube was then inserted, and the sample holder was sealed off and attached to the nitrogen-sorption apparatus.

Prior to the nitrogen-adsorption measurements, all samples were evacuated until the pressure dropped to between $10^{-5}$ and $10^{-6} \mathrm{~mm}$ of mercury, the sample occupying a position between the pumps and the gage. Evacuation was carried out at room temperature instead of at the higher temperature of $100^{\circ}$ to $110^{\circ} \mathrm{C}$ frequently used in preparing silica gel, bone char, and similar materials for nitrogen-sorption measurements. The lower temperature was considered necessary inasmuch as cotton samples that had been evacuated at $100^{\circ}$ to $110^{\circ} \mathrm{C}$ were found to adsorb slightly less nitrogen than those that had been evacuated at room temperature.

\section{Results and Discussion}

Before the procedure described above was adopted for the preparation of swollen samples for surfacearea measurements, several experiments were carried out on the effect of variations in the procedure used in the earlier work [1]. The purpose of the experiments was to aid in the selection of conditions that would give reproducible data and that would give maximum retention of the expanded structure produced by swelling. As the results of the experiments provide information on the behavior of cotton during swelling and exchange, they are discussed in some detail.

In one set of experiments, surface-area measurements were made on $101-\mathrm{g}^{*}$ samples of purified cotton linters that had been subjected to the same swelling and dehydration procedure but which differed with respect to the nonpolar liquid used in the exchange process and the conditions under which this liquid was removed. The samples were swollen by immersion in distilled water for $1 \mathrm{hr}$, dehydrated with methanol, and the methanol replaced with $n$-pentane or benzene as described in the preceding section of this report. After removal of the nonpolar liquid under the conditions shown in columns 3 and 4 of table 1, surface-area measurements were made in the usual way. In some cases, the weight of the sample and holder was recorded at various stages of the process, thus making it possible to determine how completely the liquids used in swelling and exchange had been removed.

The results, given in the last column of table 1 , show that the maximum surface area observed, 59 $\mathrm{m}^{2} / \mathrm{g}$, was obtained with the sample from which the nonpolar liquid pentane was removed by a stream of dry nitrogen gas at $0^{\circ} \mathrm{C}$. Apparently, the use of low temperature for removing the nonpolar liquid results in less collapse of the expanded cellulose. On the other hand, if the temperature is too low or the liquid is not sufficiently volatile, incomplete

TABLE 1. Effect of temperature and manner of removal of benzene or pentane on specific surface of swollen cotton linters

\begin{tabular}{|c|c|c|c|c|c|c|}
\hline \multirow{2}{*}{$\begin{array}{c}\text { Experi- } \\
\text { ment }\end{array}$} & \multirow{2}{*}{$\begin{array}{l}\text { Non- } \\
\text { polar } \\
\text { liquid }\end{array}$} & \multirow{2}{*}{$\begin{array}{c}\text { Temperature } \\
\text { surrounding } \\
\text { sample holder } \\
\text { during } \\
\text { removal of } \\
\text { nonpolar liquid }\end{array}$} & \multirow{2}{*}{$\begin{array}{l}\text { Method used for } \\
\text { removal of non- } \\
\text { polar liquid }\end{array}$} & \multicolumn{2}{|c|}{$\begin{array}{l}\text { Liquid retained } \\
\text { (based on } \\
\text { original weight } \\
\text { of cotton) } \\
\text { after- }\end{array}$} & \multirow{2}{*}{$\begin{array}{l}\text { Spe- } \\
\text { cific } \\
\text { sur- } \\
\text { face }\end{array}$} \\
\hline & & & & $\begin{array}{c}\text { Re- } \\
\text { moval } \\
\text { of non- } \\
\text { polar } \\
\text { liquid }\end{array}$ & $\begin{array}{l}\text { Evacu- } \\
\text { ation } \\
\text { and } \\
\text { surface } \\
\text { area } \\
\text { meas- } \\
\text { ure- } \\
\text { ment }\end{array}$ & \\
\hline 1.. & Benzene- & $\begin{array}{l}\text { Water bath, } \\
20^{\circ} \mathrm{C} \text {. }\end{array}$ & $\begin{array}{l}\text { Dried nitrogen } \\
50 \mathrm{ml} / \mathrm{min} \text { for } \\
18-24 \mathrm{hr} \text {. }\end{array}$ & Percent & Percent & $\begin{array}{c}m^{2} / g \\
47\end{array}$ \\
\hline 3. & do & $\begin{array}{l}\text { Room temper- } \\
\text { ature, } 23^{\circ} \text { to } \\
28^{\circ} \mathrm{C} \text {. } \\
\text { Water bath, }\end{array}$ & .... do & & & 44 \\
\hline 4. & ... do & $\begin{array}{l}\text { Water bath, } \\
83^{\circ} \text { to } 66^{\circ} \mathrm{C} \text {. }\end{array}$ & $\begin{array}{l}\text { Dried nitrogen } \\
200 \mathrm{ml} / \mathrm{min} \text { for }\end{array}$ & & & 36 \\
\hline $5 \ldots$ & ... do & $\begin{array}{l}\text { Room temper- } \\
\text { ature, } 23^{\circ} \text { to } \\
28^{\circ} \mathrm{C} . \\
\text { Water bath. }\end{array}$ & $\begin{array}{l}\text { Intermittent } \\
\text { evacuation } \\
\text { with } \mathrm{H}_{2} \mathrm{O} \\
\text { pump for } 1 \mathrm{hr} \text {. }\end{array}$ & & & 52 \\
\hline $7 \ldots$ & Pentane & $\begin{array}{l}30^{\circ} \mathrm{C} . \\
\text { Water bath, } \\
24^{\circ} \mathrm{C} .\end{array}$ & $\begin{array}{l}\text { Dried nitrogen } \\
50 \mathrm{ml} / \mathrm{min} \text { for } \\
18 \text { to } 24 \mathrm{hr} \text {. }\end{array}$ & 0.3 & & 46 \\
\hline $\begin{array}{l}8 \ldots . . \\
9 \ldots\end{array}$ & (_._do_.... & $\begin{array}{l}\text { Ice bath, } 0^{\circ} \mathrm{C} \text { - } \\
\text { Ice-salt bath, }\end{array}$ & do do & $\begin{array}{r}.8 \\
2.5\end{array}$ & $\begin{array}{r}0.0 \\
.4\end{array}$ & $\begin{array}{l}59 \\
52\end{array}$ \\
\hline $10 \ldots$ & ...do do... & $\begin{array}{l}\text { Dry ice, }-78.5^{\circ} \\
\text { C. }\end{array}$ & $\begin{array}{l}\text { Dried nitrogen } \\
50 \mathrm{ml} / \mathrm{min} \text { for } \\
90 \text { to } 96 \mathrm{hr} \text {. }\end{array}$ & 5.4 & .7 & 32 \\
\hline
\end{tabular}

a Specific surfaces reported in tables 1 to 10 , unless otherwise indicated, were calculated from ad sorption of nitrogen at $-195.8^{\circ} \mathrm{C}$, using the equation of Brunauer, Emmett, and Teller. 
removal of the liquid with a consequent decrease in available surface is to be expected.

In a second set of experiments, $2-\mathrm{g}$ samples of a commercial absorbent cotton were swollen for varying periods of time by immersion in distilled water at room temperature, by shaking in distilled water at room temperature, and by immersion in boiling distilled water. At the end of the swelling periods, the samples were subjected to solvent exchange and dried (using the standard procedure described in the preceding section), evacuated, and then used for surface-area measurements. The values obtained, presented in table 2 and figure 2 , show that specific surface increases rapidly during the first few minutes of contact with water; thereafter, it continues to increase at a much less rapid rate. This suggests that use of very short swelling periods would give results of poorer reproducibility than longer periods. Agitation and heating during swelling are shown to result in increased surface. The results indicate, however, that small fluctuations such as occur in the temperature of the laboratory would have little effect on specific surface. Accordingly, it was assumed that swelling in water at room temperature for $24 \mathrm{hr}$ would give results of satisfactory reproducibility.

The possibility that rapid removal of water from cellulose during solvent exchange might result in collapse of the expanded cellulose is suggested by the biologists' experience in preparing specimens for embedding and sectioning. Kistler [8] failed to find evidence of collapse when rapid dehydration was used in the preparation of aerogels from cellophane. He did not, however, compare the surface areas of aerogels prepared by rapid and by gradual replacement of water. As such a comparison was considered of interest, surface-area measurements were made on two swollen samples of purified cotton whose preparation differed only with respect to the method used to replace the water with absolute methanol. At the end of the swelling period, one sample was transfered to methanol solutions of gradually increasing concentration until absolute methanol was reached. In order that equilibrium be reached in each concentra-

TABLE 2. Effect of variations in procedure during swelling on specific surface of absorbent cotton

\begin{tabular}{|c|c|c|c|c|}
\hline \multirow[b]{2}{*}{ Time of swelling } & \multicolumn{4}{|c|}{ Specific surface of the absorbent cotton } \\
\hline & $\begin{array}{l}\text { Sample nei- } \\
\text { ther swollen } \\
\text { nor ex- } \\
\text { changed }\end{array}$ & $\begin{array}{l}\text { Sample swol- } \\
\text { len by immer- } \\
\text { sion in water } \\
\text { at room tem- } \\
\text { perature, } \\
\text { then ex- } \\
\text { changed and } \\
\text { dried }\end{array}$ & $\begin{array}{l}\text { Sample swol- } \\
\text { len by shak- } \\
\text { ing in water } \\
\text { at room tem- } \\
\text { perature, } \\
\text { then ex- } \\
\text { changed and } \\
\text { dried }\end{array}$ & $\begin{array}{l}\text { Sample swol- } \\
\text { len by im- } \\
\text { mersion in } \\
\text { boiling } \mathrm{H}_{2} \mathrm{O}, \\
\text { then ex- } \\
\text { changed and } \\
\text { dried }\end{array}$ \\
\hline $0 \ldots$ & $\begin{array}{l}m^{2} / g \\
0.8\end{array}$ & $m^{2} / g$ & $m^{2} / g$ & $m^{2} / g$ \\
\hline 5 min... & $\cdots$ & $\begin{array}{l}5 \\
5\end{array}$ & & 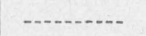 \\
\hline $\begin{array}{l}15 \mathrm{~min} \\
1 \mathrm{hr} \\
3 \mathrm{hr}\end{array}$ & $\ldots$ & $\left\{\begin{array}{r}7 \\
7\end{array}\right.$ & 11 & $\begin{array}{l}11 \\
12 \\
10 \\
14\end{array}$ \\
\hline $20 \mathrm{hr} \ldots \ldots$ & (n) & 10 & $\left\{\begin{array}{l}12 \\
12\end{array}\right.$ & \\
\hline $23 \mathrm{hr}$ & - & - & (n) & $\begin{array}{l}15 \\
16\end{array}$ \\
\hline
\end{tabular}

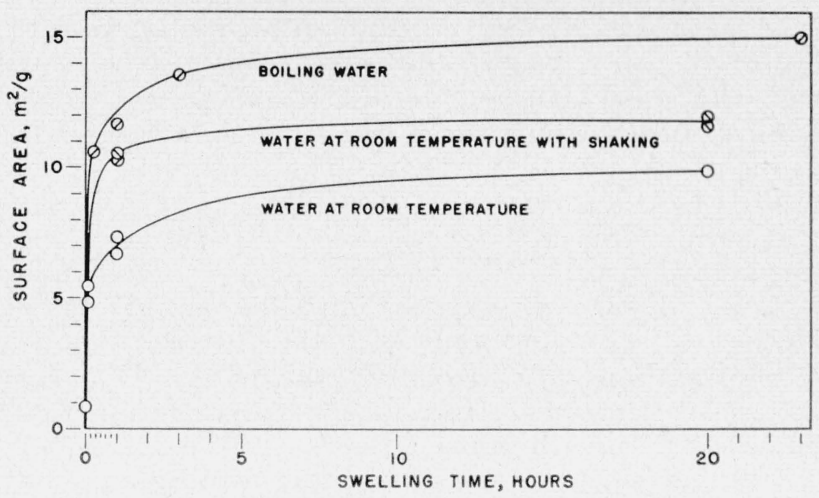

FIgURE 2. Variation in surface area of absorbent cotton with time of swelling

tion, several days were allowed for the dehydration process. The second sample was placed in the sample tube at the end of the swelling period and subjected to the usual rapid replacement of water with methanol. In both samples, the replacement of methanol with pentane and the removal of pentane were done in the usual way. As the specific surfaces of the two samples were found to be essentially the same, it was concluded that nothing was to be gained by gradual replacement of water with methanol.

As a result of the difficulty encountered in wetting raw cotton with water, the possibility of swelling the cottons in water containing a small amount of a wetting agent, 0.5 percent, then washing with water before subjecting to solvent exchange and drying was considered. Samples prepared in this way usually had lower specific surfaces, irrespective of the nature of the wetting agent, than those swollen in water, thus suggesting that washing failed to remove all of the wetting agent. Accordingly, the use of wetting agents was abandoned.

In table 3 are given the results of specific-surface measurements on swollen and unswollen specimens

TABLE 3. Specific surface of raw cottons

\begin{tabular}{|c|c|c|c|c|c|}
\hline \multirow{2}{*}{ Cotton } & \multirow{2}{*}{$\underset{\text { rity }}{\text { Matu- }}$} & \multirow{2}{*}{$\left|\begin{array}{c}\text { Weight } \\
\text { fineness } \\
\text { byarray a }\end{array}\right|$} & \multicolumn{2}{|c|}{$\begin{array}{l}\text { Specific surface of } \\
\text { unswollen cotton } \\
\text { by- }\end{array}$} & \multirow{2}{*}{$\begin{array}{l}\text { Specific sur } \\
\text { face after } \\
\text { swelling in } \\
\text { water, fol- } \\
\text { lowed by } \\
\text { solvent ex- } \\
\text { change and } \\
\text { drying by } \\
\text { nitrogen } \\
\text { sorption }\end{array}$} \\
\hline & & & $\begin{array}{c}\text { Aeral- } \\
\text { ometer }{ }^{2}\end{array}$ & $\begin{array}{l}\text { Nitrogen } \\
\text { sorption }\end{array}$ & \\
\hline Memphis $\mathrm{B} / 376839$ & $\begin{array}{c}\text { Percent } \\
38\end{array}$ & $\mu g / i n$. & $\begin{array}{l}m^{2} / g \\
0.56\end{array}$ & $\begin{array}{r}m^{2} / g \\
0.8\end{array}$ & $\begin{array}{c}m^{2} / g \\
34\end{array}$ \\
\hline Empire AP845 & 68 & 4.1 & .31 & $\begin{array}{l}.6 \\
.7 \\
.6 \\
.7\end{array}$ & $\begin{array}{c}21 \\
-1 \\
-0 \\
\end{array}$ \\
\hline Empire 2B/92. & 69 & 4.2 & .32 & .6 & $\begin{array}{l}28 \\
30\end{array}$ \\
\hline Stoneville $2 \mathrm{C}$ & 82 & 4.2 & .31 & .6 & - \\
\hline Deltapine PC-2799_. & 86 & 4.3 & .29 & $\begin{array}{l}.5 \\
.5\end{array}$ & - \\
\hline Lockett 140 & 93 & 5.6 & .24 & .4 & $\begin{array}{l}26 \\
23\end{array}$ \\
\hline $\begin{array}{l}\text { AHA PC-2868 } \\
\text { Iquitos PC-2867 }\end{array}$ & $\begin{array}{l}94 \\
96\end{array}$ & $\begin{array}{l}3.8 \\
8.0\end{array}$ & $\begin{array}{l}.27 \\
.18\end{array}$ & $\begin{array}{l}.0 \\
.3 \\
.3\end{array}$ & - \\
\hline
\end{tabular}

- Measurements made by Southern Regional Research Laboratory of the U. S. Department of Agriculture. The results of aeralometer measurements were converted from square millimeters per cubic millimeters to square meters per gram
by assuming the density of cotton to be $1.52 \mathrm{~g} / \mathrm{cm}^{3}$. 
of a number of raw cottons differing in variety, maturity, and weight fineness. The results show that the unswollen cottons varied in specific surface from 0.8 to $0.3 \mathrm{~m}^{2} / \mathrm{g}$ with the cottons falling in the order of increasing maturity when arranged in the order of decreasing specific surface. The fact that the values obtained for the specific surfaces of the unswollen cottons are slightly greater than those obtained by the arealometer method [9], also given in the table, is consistent with the thought that the latter method measures only the external surface, whereas the former also measures the lumen and channels within the fiber.

The four cottons measured after swelling in water, solvent exchange, and drying varied in specific surface from 20 to $34 \mathrm{~m}^{2} / \mathrm{g}$. Although the immature Memphis cotton had a greater specific surface than the other swollen cottons, there appears to be no correlation between degree of maturity and the increase in specific surface resulting from treatment with water followed by solvent exchange and drying. In fact, samples taken from two bales of Empire cotton having essentially the same degree of maturity differed in specific surface when swollen by approximately $9 \mathrm{~m}^{2} / \mathrm{g}$.

The results given in table 4 show the effect of various purification treatments on the specific surface of Empire cotton before and after swelling. They indicate that the removal of impurities produces little, if any, change in the specific surface of unswollen cotton. The surface area available after swelling was found to be the same in raw cotton and in cotton that had been dewaxed by extraction with boiling ethanol for $6 \mathrm{hr}$; in cotton that had been dewaxed and then freed of pectic substances by boiling in 1-percent sodium hydroxide in the absence of air for $2 \mathrm{hr}$, the surface area increased approximately $24 \mathrm{~m}^{2} / \mathrm{g}$, an increase of 110 percent. Removal of pectic substances by autoclaving at $120^{\circ} \mathrm{C}$ in 1-percent sodium hydroxide solution for $2 \mathrm{hr}^{4}$ resulted in an increase of approximately $7 \mathrm{~m}^{2} / \mathrm{g}$ or 33 percent. As the wax is believed to be confined to the outer surface, whereas the pectic substances are distributed throughout the fiber, it is not surprising that removal of pectic substances should have a greater effect on the specific surface of the swollen fiber than does removal of wax. Why removal of the impurities at atmospheric pressure should result in a greater increase than removal under increased pressure is unknown. That the use of increased pressure during purification does give a lesser increase in the surface available after swelling is further suggested by the results of surface-area measurements on yarns that had been purified by open-boiling in 2-percent sodium hydroxide solution for $2 \mathrm{hr}$ and by kierboiling in 2- to 3-percent sodium hydroxide solution for $6 \mathrm{hr}$ at $120^{\circ} \mathrm{C}$, respectively, then swollen in water containing 0.5-percent Aerosol OT, washed with water, exchanged, and dried in the usual manner. These results are shown in table 5 . It is of interest that Gailey [10] found the barium hydroxide sorptive capacity of kierboiled cottons to

\footnotetext{
4 The sample purified according to this procedure was supplied by R. E. Reeve of the Southern Regional Research Laboratory, U. S. Department of Agriculture.
}

be less than that of cottons purified by boiling for 1 $\mathrm{hr}$ in 1 -percent olive oil soap containing 0.2 percent of sodium carbonate. He attributed the decrease in sorptive capacity to increased crystallinity.

Specific-surface measurements obtained on two partially methylenated cottons prepared by reaction of an acetone solution of formalin with raw cotton [11] are shown in table 6 . Both products contained approximately 0.3 percent of formaldehyde, but one was prepared from air-dried cotton, the other from cotton that had been wet with water and then squeezed free of excess water. The former product was resistant to dyeing with direct dyes, whereas the latter resembled the original cotton in dyeing behavior. Both the dye-resistant character of this methylenated cotton, and the relatively small increase in specific surface, around $3 \mathrm{~m}^{2} / \mathrm{g}$, produced by swelling and exchange of the methylenated product from air-dried cotton, support the conclusion that the formaldehyde is present in the form of crosslinks that interfere with swelling $[11,12]$. The larger increase in specific surface, approximately $19 \mathrm{~m}^{2} / \mathrm{g}$, produced by swelling of the methylenated product from prewet cotton indicates that the position of the crosslinks in this product is such that the cotton retains much but not all of its swelling ability. That these crosslinks do not serve to hold the cellulose in the expanded condition is shown by the fact that the spe-

TABLE 4. Effect of purification on specific surface of cotton

\begin{tabular}{|c|c|c|}
\hline Cotton & $\begin{array}{l}\text { Specific } \\
\text { surface } \\
\text { of un- } \\
\text { swollen } \\
\text { cotton }\end{array}$ & $\begin{array}{l}\text { Specific sur- } \\
\text { face after } \\
\text { swelling } \\
\text { in water, } \\
\text { followed } \\
\text { by solvent } \\
\text { exchange, } \\
\text { and drying }\end{array}$ \\
\hline & $\begin{array}{r}m^{2} / g \\
0.6 \\
.6\end{array}$ & $\begin{array}{l}m^{2} / g \\
21 \\
21\end{array}$ \\
\hline Empire AP845, raw .... & $\begin{array}{l}.7 \\
.6\end{array}$ & (n) \\
\hline $\begin{array}{l}\text { Empire A P845, after extraction with boiling eth- } \\
\text { anol }\end{array}$ & $\begin{array}{l}.5 \\
.6\end{array}$ & $\begin{array}{l}21 \\
21\end{array}$ \\
\hline $\begin{array}{l}\text { Empire APP45, after extraction with boiling eth- } \\
\text { anol followed by boiling in } 1 \% \mathrm{NaOH} \text { for } 4 \mathrm{hr} \\
\text { in absence of air }\end{array}$ & .7 & $\begin{array}{l}48 \\
45\end{array}$ \\
\hline $\begin{array}{l}\text { Empire AP845, after autoclaving in } 1 \% \mathrm{NaOH} \\
\text { at } 120^{\circ} \mathrm{C} \text { for } 2 \mathrm{hr}\end{array}$ & & $\begin{array}{l}28 \\
24\end{array}$ \\
\hline
\end{tabular}

TABLE 5. Effect of method of purification on specific surface of cotton yarn

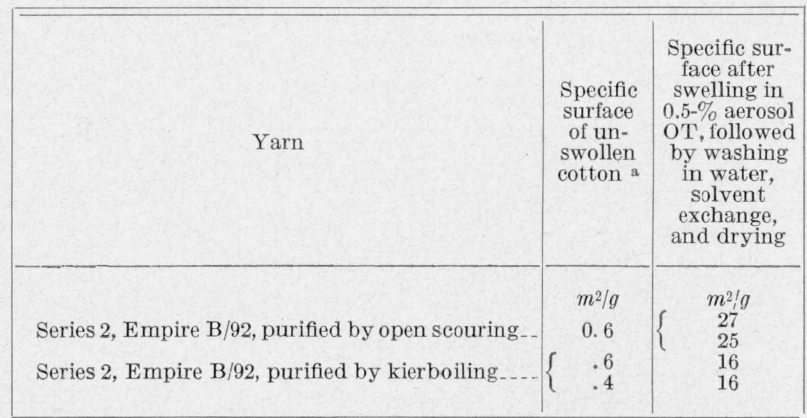

a As 2- to 3-g. samples were used for these measurements, the values obtained are regarded as approximate. 
cific surface on the unswollen, partially methylenated product prepared from prewet cotton is of the same order of magnitude as that of the original cottonless than $1 \mathrm{~m}^{2} / \mathrm{g}$.

In table 7 are given the results of specific-surface measurements on swollen and unswollen specimens of a mature Lockett cotton and an immature Memphis cotton before and after mercerization without tension for $10 \mathrm{~min}$ in 20-percent sodium hydroxide solution at $20^{\circ} \mathrm{C}$. Although the measurements on the unswollen mercerized cottons were made on 2- to $3-\mathrm{g}$ samples and are thus to be regarded as only approximate, they suggest that mercerization results in a decrease in the surface available before swelling. However, the area available to nitrogen after swelling, exchange, and drying increased on mércerization from approximately 25 to $100 \mathrm{~m}^{2} / \mathrm{g}$ for the mature Lockett cotton and from 34 to $148 \mathrm{~m}^{2} / \mathrm{g}$ for the immature Memphis cotton. That mercerization would result in an increase in the surface available after swelling is to be expected from published observations that mercerization of cotton without tension results in increased sorption of moisture [13, 14] and of alkalis $[10,15]$ and dyes [16] from aqueous solution. Exact interpretation of the results, however,

TABLE 6. Effect of methylenation on specific surface of cotton

\begin{tabular}{|c|c|c|c|c|}
\hline Cotton & $\begin{array}{c}\text { Formal- } \\
\text { dehyde } \\
\text { content a }\end{array}$ & $\begin{array}{l}\text { Color pro- } \\
\text { duced with } \\
\text { direct blue } \\
\text { dye a }\end{array}$ & $\begin{array}{l}\text { Specific } \\
\text { surface } \\
\text { of un- } \\
\text { swollen } \\
\text { cotton }\end{array}$ & $\begin{array}{l}\text { Specific } \\
\text { surface } \\
\text { after } \\
\text { swelling } \\
\text { in water, } \\
\text { followed } \\
\text { by solvent } \\
\text { exchange } \\
\text { and dry- } \\
\text { ing }\end{array}$ \\
\hline Empire B/92 $\ldots$ & Percent & Full blue.... & $\begin{array}{l}m^{2} / g \\
\mathrm{~b} 0.6\end{array}$ & $\left\{\begin{array}{c}m^{2} / g \\
30\end{array}\right.$ \\
\hline $\begin{array}{l}\text { M e th y le na te d cotton } \\
\text { (157) prepared from air- } \\
\text { dried Empire B/92. } \\
\text { Me th y le nat ed cotton } \\
\text { (158) prepared from pre- } \\
\text { wet Empire B/92. }\end{array}$ & $\begin{array}{r}0.31 \\
.26\end{array}$ & $\begin{array}{l}\text { Blue-white- } \\
\text { Full blue }\end{array}$ & $\left\{\begin{array}{r}.8 \\
.8 \\
\text { b. } 5 \\
\text { b. } 5\end{array}\right.$ & $\begin{array}{r}2 \\
6 \\
19 \\
19\end{array}$ \\
\hline
\end{tabular}

a Data supplied by C. F. Goldthwait, of the Southern Regional Research Laboratory, U. S. Department of Agriculture.

$\mathrm{b}$ As 2- to 8-g samples were used for these measurements, the values obtained are regarded as approximate.

TABLE 7. Effect of mercerization without tension on specific surface of cotton

\begin{tabular}{|c|c|c|}
\hline Cotton & $\begin{array}{l}\text { Specific } \\
\text { surface } \\
\text { of un- } \\
\text { swollen } \\
\text { cotton }\end{array}$ & $\begin{array}{l}\text { Specific sur- } \\
\text { face after } \\
\text { swelling in } \\
\text { water, fol- } \\
\text { lowed by } \\
\text { solvent ex- } \\
\text { change and } \\
\text { drying }\end{array}$ \\
\hline Memphis B $/ 376839$, not mercerized ..... & $\begin{array}{r}m^{2} / g \\
0.8\end{array}$ & $\begin{array}{c}m^{2} / g \\
34\end{array}$ \\
\hline $\begin{array}{l}\text { Memphis } \mathrm{B} / 376839 \text {, completely mercerized with- } \\
\text { out tension }\end{array}$ & a. 2 & 148 \\
\hline Lockett 140, not mercerized & .4 & $\begin{array}{l}26 \\
23\end{array}$ \\
\hline $\begin{array}{l}\text { Lockett } 140 \text {, completely mercerized without } \\
\text { tension }\end{array}$ & a. 2 & 100 \\
\hline
\end{tabular}

a As 2- to 3-g samples were used for these measurements, the values obtained are regarded as approximate. is made difficult by the fact that several changes that might influence the swelling behavior of the fiber occur during mercerization. In addition to the conversion of the water-impermeable crystal lattice of cellulose I to the water-permeable crystal lattice of cellulose II [17], decreases occur in the total amount of crystalline cellulose, crystallite size, orientation, and degree of polymerization.

Segal, Nelson, and Conrad [18] have shown that treatment of cotton with alkylamines results in decreases in degree of crystallinity and crystallite size, and an increase in moisture sorption. As swelling is believed to be confined to the amorphous regions, it was assumed that alkylamine treatment would result in an increase in the surface available to nitrogen after swelling, exchange, and drying. The results given in table 8 show, however, that reduction of the crystallinity of cotton yarn from $90.8 \pm 1.6$ percent to $43.3 \pm 10.7$ percent by treatment for $4 \mathrm{hr}$ with ethylamine in the cold and under nitrogen produced little if any change in the surface available to nitrogen both before and after swelling. A possible explanation is that the crystalline regions, although reduced in size, are present in sufficient number to limit the movement of cellulose chains as they pass through the enlarged amorphous regions, thereby preventing increased swelling of these regions.

Unexpected results (table 9) were also obtained when surface-area measurements were made on hydrocellulose prepared by the reaction of lightly kiered and bleached cotton with 2.5-molar hydrochloric acid for $4 \mathrm{hr}$ at $100^{\circ} \mathrm{C}$. As hydrolysis is believed to result in the removal of the amorphous

TABLE 8. Effect of reduction in crystallinity by amine treatment on specific surface of cotton yarn

\begin{tabular}{|c|c|c|c|}
\hline Yarn & $\begin{array}{l}\text { Crystal- } \\
\text { linity a }\end{array}$ & $\begin{array}{l}\text { Specific } \\
\text { surface } \\
\text { of un- } \\
\text { swollen } \\
\text { yarn b }\end{array}$ & $\begin{array}{l}\text { Specific sur- } \\
\text { face after } \\
\text { swelling in } \\
\text { water, fol- } \\
\text { lowed by } \\
\text { solvent ex- } \\
\text { change and } \\
\text { drying }\end{array}$ \\
\hline $\begin{array}{l}\text { Co-3647, control yarn } \\
\text { Co-3978, prepared from above by } \\
\text { ethylamine treatment. }\end{array}$ & $\begin{array}{c}\text { Percent } \\
90.8 \pm 1.6 \\
43.3 \pm 10.7\end{array}$ & $\left\{\begin{array}{r}m^{2} / g \\
0.2 \\
.5 \\
.7 \\
.8\end{array}\right.$ & $\begin{array}{l}m^{2} / g \\
21 \\
18 \\
16 \\
23\end{array}$ \\
\hline
\end{tabular}

a Measurements made by C. M. Conrad of the Southern Regional Research Laboratory, U. S. Department of Agriculture.

b As 2- to 3-g samples were used for these measurements, the values obtained are regarded as approximate.

TABLE 9. Effect of treatment with water followed by solvent exchange and drying on specific surface of hydrocellulose

\begin{tabular}{|c|c|}
\hline Sample & $\begin{array}{l}\text { Specific } \\
\text { surface }\end{array}$ \\
\hline Air-dried & $\left\{\begin{array}{c}m^{2} g \\
0.7 \\
.6\end{array}\right\}$ (a) \\
\hline $\begin{array}{l}\text { Solvent exchanged and dried } \\
\text { Treated with water, solvent exchanged, and dried }\end{array}$ & $\left\{\begin{array}{c}6 \\
127 \\
125\end{array}\right.$ \\
\hline
\end{tabular}

a As 2- to 8- g samples were used for these measurements, the values obtained are regarded as approximate. 
regions of cellulose by dissolution and recrystallization, it was expected that the specific surface of airdried hydrocellulose would be greater than that of air-dried cotton but would show no increase when the hydrocellulose was treated with water, subjected to solvent exchange, and dried. Instead, it was found that the specific surface of air-dried hydrocellulose was essentially the same as that of cotton fiber, and on treatment with water, followed by solvent exchange and drying, it increased to $126 \mathrm{~m}^{2} / \mathrm{g}$. In order to determine whether this increase might be the result of the dehydrating action of the solvents used in the exchange process rather than the result of swelling, a sample of the hydrocellulose was subjected to solvent exchange and drying without the usual treatment with water. This resulted in a specific surface of approximately $6 \mathrm{~m}^{2} / \mathrm{g}$, an increase of the magnitude to be expected as the result of removal of the normal regain moisture by solvent exchange. Thus it appears that treatment with water plays an important role in the development of the larger surface area of $126 \mathrm{~m}^{2} / \mathrm{g}$, possibly by separating close-fitting crystallites sufficiently for all or most of their surfaces to be available to nitrogen. ${ }^{5}$

The results of specific-surface measurements on a series of methanolyzed celluloses prepared by reaction of purified cotton with 0.5 molar hydrochloric acid in absolute methanol at $30^{\circ} \mathrm{C}$ for varying periods of time are given in table $10 .^{6}$ They show that the surface available to nitrogen after swelling decreases rapidly during the first few hours of methanolysis and then increases; the products of 5, 50, and $240 \mathrm{hr}$ of methanloysis having specific surfaces approximately $1 / 3,1 / 4$, and $1 / 2$ as large, respectively, as that of the purified cotton used in their preparation. Between 240 and $976 \mathrm{hr}$ of methanolysis, little if any further change occurs. This suggests the operation of two forces: one resulting in a reduction in the surface available after swelling, the other in an increase. The former is explicable in terms of the removal of amorphous cellulose by dissolution or recrystallization; the latter by the separation of close-fitting crystallites, upon treatment with water followed by solvent exchange, so that all surfaces are available to nitrogen. That two forces also operate during the hydrolysis of cellulose is suggested by surface areas calculated from water sorption data ${ }^{7}$ on hydrocelluloses prepared from cotton and viscose rayon (table 11).

The results of this investigation suggest that nitrogen-sorption measurements on swollen cottons may be used in evaluating the effect of various treatments on cottons and other cellulose fibers. In interpreting these measurements, however, it must be borne in mind that some collapse of the expanded cellulose undoubtedly occurs during the exchange and drying procedure with the result that the specific surfaces

\footnotetext{
3 Nelson [19] found that hydrocellulose was reduced to very fine particles on beating in a Waring blender for only 30 sec. Measurements on electron micrographs of these particles indicated that their surface area was of the same order of magnitude as that of water-treated, solvent-exchanged hydrocellulose.

of magnitude as that of water-treated, solvent-exchanged hydrocellulose.

7 These moisture sorption data were obtained at the request of C. M. Conrad of the Southern Regional Research Laboratory for use in another project.
}

of these samples are not those of completely swollen cottons. How great the collapse is, or to what extent it is responsible for the fact that the values obtained for specific surfaces of swollen cottons by the nitrogen method are much smaller than those obtained by other methods (table 12) is yet to be determined.

\section{TABLE 10. Effect of methanolysis on specific surface of cotton cellulose}

Methanolysis carried out at $30^{\circ} \mathrm{C}$ in $0.5-M$ HCl in absolute methanol.

\begin{tabular}{|c|c|c|}
\hline Sample & $\begin{array}{l}\text { Specific } \\
\text { surface } \\
\text { of un- } \\
\text { swollen } \\
\text { cellulose a }\end{array}$ & $\begin{array}{l}\text { Specific sur- } \\
\text { face after } \\
\text { treatment } \\
\text { with water } \\
\text { followed by } \\
\text { solvent ex- } \\
\text { change and } \\
\text { drying }\end{array}$ \\
\hline $\begin{array}{l}\text { 1. Purified Empire cotton } \\
\text { 2. Prepared from } 1 \text { by methanolysis for } 1 \mathrm{hr} \\
\text { 3. Prepared from } 1 \text { by methanolysis for } 5 \mathrm{hr} \\
\text { 4. Prepared from } 1 \text { by methanolysis for } 50 \mathrm{hr} \\
\text { 5. Prepared from } 1 \text { by methanolysis for } 240 \mathrm{hr} \\
\text { 6. Prepared from } 1 \text { by methanolysis for } 600 \mathrm{hr} \\
\text { 7. Prepared from } 1 \text { by methanolysis for } 976 \mathrm{hr}\end{array}$ & $\left\{\begin{array}{r}m^{2} / g \\
0.4 \\
.7 \\
\hdashline \\
\hdashline \\
1.6 \\
1.9\end{array}\right.$ & $\left\{\begin{array}{c}m^{2} / g \\
28 \\
24 \\
20 \\
17 \\
9 \\
6 \\
7 \\
11 \\
16 \\
16 \\
20 \\
16 \\
14\end{array}\right.$ \\
\hline
\end{tabular}

as 3-g samples were used for these measurements, the values obtained are regarded as approximate.

TABLE 11. Effect of hydrolysis on specific surface of cotton and viscose rayon

\begin{tabular}{|c|c|}
\hline Sample & $\begin{array}{l}\text { Specific } \\
\text { Surface }\end{array}$ \\
\hline $\begin{array}{l}\text { Co-4152, cotton } \\
\text { Co-4153, prepared from } \mathrm{Co}-4152 \text { by hydrolysis for } 20 \mathrm{~min} \\
\mathrm{Co}-4154 \text {, prepared fiom } \mathrm{Co}-4152 \text { by hydrolysis for } 7 \mathrm{hr} \\
\mathrm{Co}-4155 \text {, viscose rayon. } \\
\text { Co-4156, prepared from } \mathrm{Co}-4155 \text { by hydrolysis for } 6 \mathrm{~min} \\
\text { Co-4157, prepared from } \mathrm{Co}-4155 \text { by hydrolysis for } 1.5 \mathrm{hr}\end{array}$ & $\begin{array}{r}m^{2} / g \\
114 \\
84 \\
95 \\
193 \\
130 \\
145\end{array}$ \\
\hline
\end{tabular}

\& Specific surfaces calculated from adsorption of water at $35^{\circ} \mathrm{C}$, using the Brunauer, Emmett, and Teller equation.

TABLE 12. Specific surface of swollen cotton as determined by methods other than low-temperature nitrogen sorption

\begin{tabular}{|c|c|c|c|}
\hline Sample & Method & $\begin{array}{l}\text { Specific } \\
\text { surface }\end{array}$ & Reference \\
\hline $\begin{array}{l}\text { Purified cotton linters, } \\
\text { swollen in } 10 \% \\
\text { NaOH, washed, sol- } \\
\text { vent exchanged and } \\
\text { dried. } \\
\text { Purified cotton (swol- } \\
\text { len by adsorbate). } \\
\text { Do. } \\
\text { Do } \\
\text { Do } \\
\text { Do. } \\
\text { Purified cotton }\end{array}$ & $\begin{array}{l}\text { Thallous ethylate...... } \\
\text { Water vapor sorption... } \\
\text { Sulfur dioxide sorption.- } \\
\text { Ammonia gas sorption.-- } \\
\text { Hydrogen chloride gas } \\
\text { sorption. } \\
\text { Heat of swelling and } \\
\text { adhesion tension of } \\
\text { water. }\end{array}$ & $\begin{array}{r}m^{2} / g \\
170 \\
330 \\
420 \\
520 \\
\\
108 \\
\\
220 \\
130 \\
230 \\
90 \\
140\end{array}$ & $\begin{array}{l}{[21]} \\
{[22]} \\
{[22]} \\
{[22]} \\
{[22]} \\
{[22]}\end{array}$ \\
\hline
\end{tabular}




\section{Summary}

1. Unswollen cotton fibers differing in variety, maturity, and previous history showed relatively small differences in surface area as measured by the method of Brunauer, Emmett, and Teller; the surface area in all cases being less than $1 \mathrm{~m}^{2} / \mathrm{g}$.

2. Cotton fibers that had been swollen in water, then dehydrated by a process of solvent exchange, and dried under anhydrous conditions were found to have surface areas many times those of the unswollen fibers.

3. Studies on an absorbent cotton showed the increase in surface to be dependent on time and temperature of swelling.

4. When swollen and dehydrated under the same conditions, cottons differing in previous history had surface areas ranging from 4 to $148 \mathrm{~m}^{2} / \mathrm{g}$. Purification and mercerization produced increases in the surface available after swelling; methylenation produced a decrease; ethylamine treatment had no effect.

5 . Studies on a series of methanolyzed cottons suggested the operation of two forces during methanolysis, one resulting in a decrease in the surface available after swelling, the other in an increase.

6 . The correlation of the nitrogen method with other methods used for determining the specific surface of swollen cellulose requires further study.

The authors express their appreciation to John W. Rowen for suggesting this investigation and to John R. Gustafson, Jr., Charles K. Mann, and Walter $\mathrm{K}$. Stone for technical assistance.

\section{References}

[1] C. M. Hunt, R. L. Blaine, and J. W. Rowen, J. Research NBS 43, 547 (1949) RP2048.

[2] S. Brunauer, P. H. Emmett, and E. Teller, J. Am. Chem. Soc. 60, 309 (1938).
[3] A. G. Assaf, R. H. Haas, and C. B. Purves, J. Am. Chem. Soc. 66, 59 (1944).

[4] A. G. Assaf, R. H. Haas, and C. B. Purves, J. Am. Chem, Soc. 66, 66 (1944).

[5] P. H. Emmett, A new method for measuring the surface areas of finely divided materials and for determining the size of particles. Symposium on new methods for particle size determinations in the subsieve range, $p$. 95-105 (American Society for Testing Materials, Philadelphia, Pa., 1941).

[6] W. E. Barr and V. J. Anhorn, Scientific and industrial glassblowing, p. 271 (Instruments Publishing Co., Pittsburgh 12, Pa., 1949).

[7] S. Brunauer, The adsorption of gases and vapors, p. 155 (Princeton University Press, Princeton, N. J., 1945).

[8] S. S. Kistler, J. Phys. Chem. 36, 52 (1932).

[9] K. L. Hertel and C. J. Craven, Textile Research J. 21, 765 (1951).

[10] I. Gailey, J. Soc. Dyers \& Colourists 67, 357 (1951).

[11] C. F. Goldthwait, Textile Research J. 21, 55 (1951).

[12] R. E. Wagner and E. Pacsu, Textile Research J. 22, 12 (1952).

[13] A. R. Urquhart and A. M. Williams, Shirley Institute Mem. 4, 5 (1925) ; J. Textile Institute 16, T155 (1925).

[14] A. R. Urquhart and A. M. Williams, Shirley Institute Mem. 5, 303 (1926); J. Textile Institute 18, T55 (1927).

[15] S. M. Neale, J. Textile Institute 22, T320, T349 (1931).

[16] E. Knecht, J. Soc. Dyers \& Colourists 24, 68, 107 (1908).

[17] P. H. Hermans, Physics and chemistry of cellulose fibers, p. 41 (Elsevier Publishing Co., Amsterdam, 1949).

[18] L. Segal, M. L. Nelson, and C. M. Conrad, J. Phys. Chem. 55, 325 (1951).

[19] M. L. Nelson, Southern Regional Research Laboratory of the U. S. Department of Agriculture. Private Communication.

[20] R. E. Reeves, L. W. Mazzeno, and C. L. Hoffpauir, J. Am. Chem. Soc. 7\%, 4773 (1950).

[21] J. W. Rowen and R. L. Blaine, J. Research NBS 39, 479 (1947) RP1842.

[22] A. J. Stamm and M. A. Millett, J. Phys. Chem. 45, 43 (1941).

Washington, July 10, 1952. 